\title{
Psychological Aspects of Platform Business Models Risk Management
}

\author{
Alexei Valerivitch Altoukhov*, Marina Vladimirovna Kuzmina, Sergey Alexandrovitch \\ Tishchenko
}

Moscow State University, Moscow, Russia

Received: 06/07/2020 Accepted: 01/10/2020 Published: 20/12/2020

\begin{abstract}
The author of this article suggests an overview of the generic psychological principles of influence, earlier described by Robert Cialdini, and their application to enterprise management. Each principle is analyzed according to the structural points: brief description; distinction of enterprise-specific features; examples of positive and negative impact caused to the enterprise by the application of principle; introduction of management methods. Throughout the publication we draw attention to the importance of enterprise psychological risks management, because even though they are highly underestimated, they play a crucial role in the enterprise functioning and development perspective. Also, with this article, the author tries to prove that these risks can be avoided or even used to the benefit of the enterprise performance, despite the complexity of psychological risks management.
\end{abstract}

Keywords: decision-making, risk management, influence principles, platform law, business model.

\section{Introduction}

Currently, with reference to the digital innovation economy, the term "platform" is understood to mean a certain informational, conceptual, technological base for the collection, processing and transmission of certain information in the interests of the participants of this platform. A platform can be, for example, unified software, a general concept of design or promotion, certain uniform standards of development, production, implementation, use, etc. Thus, the platform is a way of organizing and standardizing processes in a digital economy. Platforms and platform law are actively developed, implemented and developed in various sectors of the economy, in modern, innovative areas of activity, including complex technical systems or events. This is due to the fact that platforms are changing the logic of the development of economic processes from "traditional" to more modern, fast, innovative. In particular, digital platforms reduce or completely eliminate many barriers to business, simplify and speed up communications, and offer new opportunities and tools for creating value. Platforms transfer traditional production to digital footprints, reducing costs and turning products into services that provide greater profit; and platform law is designed to ensure the legal side of these processes. Therefore, it is no coincidence that digital platforms are increasingly spoken of as a market - a meeting place for two or more people in order to exchange values in one form or another. We can say that in the modern economy, the platform is what provides and structures the communication and interaction of economic agents.

Regarding digital platforms directly, we add that they use a business model based on a comprehensive collection of user data, i.e. analyze information about all types of user activity. Then, the collected data is processed by the platform algorithms (for example, based on artificial intelligence) so that the resulting analytics is optimized for marketing purposes. It is self-evident that any enterprise is subjected to risks influence at all phases of its operation $[1,2,3]$. These risks might be different in a number of ways: scope of their effect, potential results, the extent of their influence, etc. Nevertheless, for the purpose of our research, we choose two vital aspects, which are typical for any enterprise risks:

Risk is based on an uncertainty: a risk always presumes some probabilistic outcome, which can be described as a potentially achieved result different from the planned one. From this perspective, it would be more reasonable to mention both the loss risk and the surplus profit risk. Any forecast outcome associated with the realization of the previously determined situation should not be related to risk category, since being "a priori no-win" they are completely predictable. In a situation of certainty there is no risk whatsoever, no matter the potential outcome of this situation [4, p. 216].

The scientific literature identifies the following types of risks that affect the activities of the organization: environmental, macroeconomic, trade and economic, currency, social, personnel, technological [4-7]. Depending on the specifics of the activity, the development strategy of the company and its resources, the probability of risk increases $[8,9]$. Hence the second major aspect:

Decision-making in cases of uncertainty depends heavily

Corresponding author: Alexei Valerivitch Altoukhov, Moscow State University, Moscow, Russia. E-mail: alexei.altoukhov@gmail.com 
on personal traits, skills, experience and even the emotional state of the person who makes the decision: uncertainty implies least two possible results of each alternative in the decisionmaking. If this case an enterprise must consider all of the potential, or at least most probable, outcomes. [4, p. 218]. The way these potential outcomes are processed, analyzed, and in the end accepted or discarded, depends directly on the leader's ability to make reasonable decisions in the environment of psychological instability which is typical for any situation of uncertainty.

In other words, the degree to which a person is affected by the emotional stress is a threat to operation of the whole enterprise. That is why it is so important for the risk management to include not only finances, competition, etc., but also the psychological markers of an enterprise ${ }^{2}$.

\section{Methods}

This involves the use of opportunities and elimination of risks, including not so obvious, like the psychological principles described by Robert Cialdini [10]. Robert Cialdini in his book "Influence: The Psychology of Persuasion" discriminates several principles which make a person act in the desired manner by affecting certain psychological stereotypes. The author suggests viewing some of these principles in their reference not to a single person or a group of people but to an enterprise. He then defines methods used to minimize the effects of these principles on decision-making. The authors of the article assume that risk minimization is a necessary condition for the creation of any business model. Therefore, relying on the obvious but important principles described by Robert Cialdini, the authors of the article in their research suggest a model for the development of effective methods of psychological risk management.

\section{The first principle: commitment}

Commitment means that people who have already made the decision think of it better than they did before the decisionmaking. Although there are no new "pro" arguments, the person commits to his actions, persuading himself that the choice he made was the right one [10, p. 70]. This is determined directly by social influence: a person has little to no respect if he always changes his mind or doubts his own decisions. Enterprises are especially "sensitive" to this principle, since any doubts about the decision made might have grave financial and reputation risks. For example, business partners will question the necessity of doing business with the company that constantly changes its suppliers, cancels the achieved agreements, etc. The case with the Merrill Lynch bank and its employee is a vivid example of how one man's decisions might lead a company to its collapse. Osman Semerci had accumulated risky assets (CDOs) for a long time, primary losses were estimated at 2.1 billion dollars minimum [11, p. 157]. At first glance it seemed strange that the company executives did not apply any sanctions to Mr Semerci, once the losses were discovered. He kept his position and continued his work until the bank collapsed. Moreover, the bank executives supported his efforts. The commitment principle gives the explanation to such 'irrational' behaviour at Merrill Lynch: termination of Semerci's employment along with the loss of 2.1 billion would also mean the loss of business reputation, and what was worse - it would question the validity of the earlier decisionmaking. In other words, the influence of the psychological principle of the commitment not only initiated risks implementation but led to a company merger.

On the other hand, some companies manage to use risks potential to their advantage with the help of the commitment principle. Take the web resource Copyblogger as an example, that sells programs for its digital content marketing platform Copyblogger Media. On the Copyblogger home page visitors are offered to subscribe for the free online training courses. The only thing needed is to provide an e-mail address, which is in fact one of the forms of public obligations. Accepted obligations increase the chances that the subscribers to free online courses will later subscribe to some paid services [12, p. 19]. Commitment to accepted obligations, even though accepted by mistake, has a strong tendency for "self-preservation", because it creates social "support points" which are especially needed for building economic relations between enterprises [11, p. 117]. Though they do "fail" and act against the enterprise interests. So, how can we control the risks that are created by the commitment principle?

Any psychological risk is hard to manage, especially when combined with other persistent risks that are more obvious and with immediate consequences. In case of the commitment principle it is more rational for the enterprise to regulate the decisions that affect business processes (for example, choosing or cancelling the supplier chain, entering a new market, etc.). The necessity to coordinate decisions with the approved regulations might prevent from emotional decision-making or accepting obligations with negative consequences for the enterprise.

\section{The second principle: reciprocation}

This principle is perfectly simple and well-known: you are somehow obliged to return a favour [10, p. 34]. The feeling of gratitude for any small favour can be so strong that even after a long time the "obliged" person will be eager to return the favour, and to a greater extent than was expected. The influence of this principle is rooted historically in the necessity to share for the community to survive. From the enterprise perspective this can be interpreted as a postponed payment: receiving a service now, the company does not spend its resources for its acquisition. On the other hand, "returning the favour" might come out with the problem of choosing between great expectations from the favour provider and "face plant", when refusing to repay the debt. In case of any achieved agreement on the provided by the contract partner service (a delayed, deferred payment, a new client, a qualified employee, etc.), an enterprise accepts the risks of mutual exchange principle. Take for example the LLC "RomMetLom" company which has several branch departments that accept ferrous and non-ferrous scrap metal. This company could not but sell its competitor one of the branches because when the company was formed and registered, this competing enterprise helped it with the supply of equipment. The terms of the deal were good, yet, it caused speculations on its effectiveness for the future of the company. The question is open for discussion if the deal would even take place, had not the companies been bound by the reciprocal relations. Examples of positive implementation of the reciprocation principle are countless. We all know companies

\footnotetext{
${ }^{2}$ In case of psychological markers of an enterprise we speak of the susceptibility degree, to which the people who are making the decisions in the enterprise are liable.
} 
built as a personal blog or exclusive training course, which offer a free trial or advice on how to earn with web marketing, or learn a foreign language fast, etc. They normally offer the first webinar or online class for free, and even with a gift of some sorts, but in the end they all ask to sign in for a full course. Statistically, the majority of clients feel obliged to accept the offer.

For a company it is harder to avoid the risks of reciprocal relations than for an individual: the enterprise cannot intuitively view some offered service as bait. First of all, the company management must differentiate between personal favours and company services, and by no means mix them together. Business services must be put on paper with clearly defined conditions of "exchange": deadlines, terms of payment, etc. This will help avoid the feeling of unpaid debts, and as the result, not to make any impractical enterprise decisions.

\section{The third principle: social proof}

According to this principle we determine what is correct by finding out other people's opinion. A behaviour is more correct in a given situation to the degree that we see others performing it [10, p. 121]. This is a very stable principle, because by acting within social norms people are usually more successful in their beginnings than acting contrary to them. This principle is especially effectively working with people who suffer from low self-esteem, people who constantly need somebody's approval. Speaking of enterprise, this is mostly relatable to the recently established structures, new on the market, without clear goals and means of its achievement. Quite often such companies find it normal to copy other companies' strategies, following in the footsteps of the leaders, which can lead them to negative consequences. As an example, we take a small hotel " $\mathrm{X}$ ", , where company's executives at the start of their business decided to follow the path of their more successful competitors. They placed information about their hotel in the hotels.com web resources. This website shows the number of people who booked the rooms in the past few hours and their reviews of the service. Being unprepared for serious competition, this hotel " $\mathrm{X}$ " received low reviews, the number of clients went down, the company could not compensate the financial losses and had to go bankrupt. The principle of social proof played against the company.

Nevertheless, if used correctly, this principle can become a very effective tool for profit increase. This is especially obvious in the case of online shops. For example, Modcloth website provides online voting for the best clothes, which is marked with label "Best Sellers". The buyers themselves are influenced by the Modcloth choice. The clothes labelled "Best Sellers" is sold much better than all the rest, bringing company more profit from sales than the clothes outside that category. When there is a similarity between the enterprises the principle of social proof has more influence [10, p. 165]. This can be the market they share, similarities of sold product, etc. In order to manage this influence the enterprises (and its executives) must create a unique identity, take the best from their rivals' experience, but follow their own path. Practically this means clear goals, strategy and tactics that would consider the specifics of the enterprise. With this approach the need to "plagiarize" the ideas of others will die out by itself, without denying the advantages of this principle.

\section{The fourth principle: liking}

According to Cialdini people tend to share views and agree with people they know well or people they like, although this feeling is based on superficial traits, such as physical appeal, kindness, etc. If we speak about companies, then this principle means that people who make the decisions tend to favour more "attractive" business partners. For example, those who have more appealing representatives, nicer people in the ads, employees with similar problems, etc. It is not uncommon, when the chance to tell potential clients about the similarities between company employees and guests increases probability of cooperation with only one feeling of sympathy, between the two sides of the deal [13, p. 196].

Nevertheless, sympathy does not always guarantee successful outcome of the decision made. The potentially negative outcome of the liking principle risks is obvious, when "Business for kids" company is studied as an example. This enterprise provided tutorship for students in economics academic disciplines. I order to increase the number of clients, this enterprise made a deal with an advertising company for the promotion of their services. The choice would seem well-grounded, unless we disregard the fact that the company was chosen on the basis of one single criterion - personal acquaintance and friendship between the managing director of "Business for kids" and the advertising company employee. Trying to help a friend, the custoter did not study the market, otherwise he would have known that the chosen advertising company had no experience in the promotion of educational institutions. The outcome: advertising campaign was unsuccessful, new clients did not sign in, the whole seasonal cycle of an academic semester the company was idle, losing profit, and in the end went bankrupt. That is an infamous example, but the number of options, when to use this principle for the company benefit is much greater. A hint of similarity with the client, dropped to him casually, can dramatically increase his loyalty [14, p. 74]. For example, many vet clinics put on the websites their employees' background that show their affection for animals, and also their own pets. This approach adds humanity to the company image and makes it more appealing to the clients.

It goes without saying that it is more pleasant to make business with partners who you like. Though decision-making based on affection only might bring the company poor results. To avoid the influence of the liking principle the company executives should list the requirements applicable to potential clients, weigh the pros and cons of a specific purchase, etc. This will make the choice less dependent on personal preferences and more on company interests. It might be a good idea to involve company employees in the analysis and decision-making process from time to time; that will help avoid biased opinion.

\section{The fifth principle: the scarcity principle (uniqueness)}

The scarcity principle means that opportunities seen more valuable to us when their availability is limited [10, p. 231]. The effect of this principle is stronger, if some object, or action, or information is suddenly unavailable; and also, if the there is competition for the restricted object, and that competition gets tougher, the more attractive the object is. For an enterprise the scarcity principle can be specified: goods, services, markets,

${ }^{3}$ With respect to information confidentiality, the company name has been replaced. 
clients, employees are more valuable, if their number is limited. For example, based on psychological preferences, when choosing a candidate for the job, the preference will be given to a graduate from an elite university; the logic behind this is that the graduate is perceived as "a rare candidate", which of course does not make him a better employee.

The scarcity principle has larger risks due to its regular efficiency, and people tend to trust it for this reason without any doubts. Nevertheless, the fewer the exceptions, the more danger they represent. A small enterprise " $Z$ " 4 that sells hand-made home appliances, making it business through the Instagram platform, offered its clients a unique product: good luck charms by local craftsman from Indonesia. Ordering, shipment, customs clearance, etc. took much time, effort and finances. This fact alone made the company owner position that small batch of items as the major product among his goods. Yet, the demand and clients' preferences were ignored, and the potential buyers were not eager to pay a higher price for that product. This outcome of improper implementation of the scarcity principle had its toll on the company: although the company is still operational, the batch of that unique charms was sold at a very low price, bringing financial losses to the company balance. There is no need to search for the successful implementation of the scarcity principle, it is right there: the sudden deficiency of normally available product, high competition and resulting uniqueness at the peak of the COVID19 pandemics was abused by the supermarkets in Russia. The price of ginger on the market tripled, and even despite this fact the demand increased by $35 \%$ after the price has skyrocketed [15]. The timely adaptation of the scarcity principle has brought good profit to the Russian sellers of ginger. Just like any other human being, a company executive is influenced by psychological patterns, especially as strong as the scarcity principle. In order to avoid its negative effects, it is enough to ask oneself a simple question: is this product (service, person, etc.) really necessary under present conditions, despite its uniqueness? The right answer requires analysis of the object, weighing its pros and cons for the maximally objective estimation.

\section{Conclusion}

Psychological risks are quite frequently ignored, and since they are underestimated and misunderstood, the methods of their management are not yet developed. Although, with proper implementation they can give a significant boost to company sales and profit. As for the defence mechanisms against psychological risks, the main recommendation would be minimizing emotional influence in the process of decision-making. To achieve this, it will be necessary to involve other key employees of the company in the analysis and solution finding (bookkeepers, department managers, etc.). This approach will show the same situation from different perspectives, and also reduce the subjective influence of a single person. Also, a significant help would be the development of basic written regulations, requirements for the major company activities (hiring new employees, choosing suppliers, estimating product qualities, etc.). The need to consult company internal regulations before making a decision will help assess the situation rationally add subjectivity and prevent negative consequences for the company. Certainly, all companies and situations are unique, but the development of suitable methods of psychological risks management is crucial for any structural unit that aims at successful operation in the market.

\section{Ethical issue}

Authors are aware of, and comply with, best practice in publication ethics specifically with regard to authorship (avoidance of guest authorship), dual submission, manipulation of figures, competing interests and compliance with policies on research ethics. Authors adhere to publication requirements that submitted work is original and has not been published elsewhere in any language.

\section{Competing interests}

The authors declare that there is no conflict of interest that would prejudice the impartiality of this scientific work.

\section{Authors' contribution}

All authors of this study have a complete contribution for data collection, data analyses and manuscript writing.

\section{References}

[1] Ilyin EP. Risk psychology. St. Petersburg: Piter Publ.; 2012. 490 p.

[2] Kaneman D, Twersky A. The theory of perspectives: decisionmaking analysis in risks environment. Ekonomika i matematicheskiye metodi [Economics and mathematical methods]. 2015; 1:3-25.

[3] Saveliyeva IP, Martirosyan LB, Beliyaev NA. Enterprise risks management in modern economic environment. Vestnik UzhnoUralskogo gosudarstvenogo universiteta: Ekonomika i menedgement. Seriya: Ekonomika i menedgement. [Journal of the South-Urals state university. Series: Economics and management]. 2012; 9:9-21.

[4] Kuzmina MV. Enterprise risks: threat or opportunity? Vestnik Rossiiskogo universiteta im. G.V. Plekhanova [Journal of the Russian university of economics named after G.V. Plekhanov]. 2019; 3:215221

[5] Vorotnikov IL, Kolotyrin KP, Romanov AV, Nayanov AV, Gutuev MS. Sustainability Risk Mitigation in Food Industry under PublicPrivate Partnership. Utopía Y Praxis Latinoamericana 2020; 25(5): 328-337.

[6] Kadeev ZK, Ponikarova AS, Zotov MA, Kadeeva EN, Kantyukov RR, Shenkarenko SV. The Issues of Sustainable Management of Innovative Industrial Risks During Sustainable Development of Entities. Journal of Advanced Research in Law and Economics 2020;11(2):400 - 409 .

[7] Bobrova AV, Stepanov EA. Model (Methodology and Calculation Formula) Combining the Influencing Factors of Transport Logistics Efficiency and Advantages by Type of Transport for Risk Reduction and Decision-making When Choosing the Best Routes. Journal of Advanced Research in Law and Economics 2020;10(2):448 - 460.

[8] Gayduk VI, Kovalchuk MD, Ermakov AA, Kamysheva SY. Risks of interaction between government bodies and business structures in the Russian agricultural sector. Revista Inclusiones 2020;7(1):188-205

[9] Katanaeva MA, Grozovsky GI, Lartseva TA, Vyacheslavova OF, Parfanyeva IE. Risk-oriented thinking in the quality management system of an organization. Revista Inclusiones 2020;7(1):310-317.

[10]Cialdini R. The Psychology of persuasion. 5th ed. (Russian ed. Psikhologiya vliyaniya). St. Petersburg: Piter Publ.; 2014. 304 p.

[11]Farrel G. Crash of the titans. (Russian ed.: Krakh titanov). Moscow: Alpina Publ.; 2012. 412 p.

${ }^{4}$ With respect to information confidentiality, the company name has been replaced. 
[12]Zhemchugov AM, Zhemchugov MK. Enterprise life cycle. Problemi ekonomiki i menedgementa [Economics and management problems]. 2012; 9:11-26.

[13]Ekman P. Psychology of deception. Lie to me, if you can. (Russian ed.: Psikhologiya lzhi. Obmani menya esli smozhesh). St. Petersburg: Piter Publ.; 2010. 304 p.

[14]Pleshakova EU. Pathology of the modern enterprise management. Effecktivnoye antikrizisnoye upravleniye [Effective anti-crisis management]. 2016; 6:72-75.

[15] Interfax. Khronika. Pandemiya koronavirusa [Chronicles. COVID-19
pandemics];
2020.
Available
from:

https://www.interfax.ru/russia/702280 